\title{
Preface: Soil processes in cold-climate environments
}

\author{
M. Oliva ${ }^{1}$, P. Pereira ${ }^{2}$, J. Bockheim ${ }^{3}$, and A. Navas ${ }^{4}$ \\ ${ }^{1}$ University of Lisbon, Centre for Geographical Studies/Institute of Geography and Spatial Planning, Alameda da \\ Universidade, s/n, 1600-214, Lisbon, Portugal \\ ${ }^{2}$ Mykolas Romeris University, Environmental Management Centre, Ateitis 20 street, Vilnius, Lithuania \\ ${ }^{3}$ UW-Madison, Department of Soil Science, 1525 Observatory Drive, Madison, WI 53706-1299, USA \\ ${ }^{4}$ EEAD-CSIC - Department of Soil and Water, Avda Montañana 1005, 50059 Zaragoza, Spain
}

Correspondence to: M. Oliva (oliva_marc@yahoo.com)

\section{Introduction}

Cold environments occupy a vast portion of Earth. Apart from polar and subpolar environments, many mountain regions and high plateaus are affected by edaphic, ecological and geomorphological processes driven by cryogenic processes. Under the generic consideration of cold climates, very different climate regimes exist. The latitude, altitude, topography, distance to moisture sources, exposure to prevailing winds and proximity to high/low-pressure systems comprise the main characteristics of the cold climate in these regions. Consequently, there is a wide range of cold-climate regimes with very different characteristics in terms of the intensity, duration and persistence of the cold season and moisture conditions. However, the general concept of cold is very relative and dependent on the topic under study. In the case of the special issue "Soil processes in cold-climate environments", the scope is on soil processes in environments affected by cold climates where the combination of temperatures, precipitation and topography allows the existence of soils. The wide variety of cold-climate regimes, together with other factors (lithology, orography, aspect), comprises the very different chemical, physical and thermal processes affecting the soils.

The influence of cold climates on the soils is reflected in the thermal regime of the ground, which controls the typology and processes affecting the soils As a result of the International Polar Year (2007-2009), there has been a significant increase in the number of papers focusing on permafrost environments. Major interest has been given to the monitoring of the thermal state of the permafrost in the Arctic (Romanovsky et al., 2010), where the recent warming may impact the dense network of settlements and infrastructures allocated there (Nelson et al., 2002). Despite the complex lo- gistics in Antarctica, there has been an increased effort in creating a network for permafrost monitoring in this continent (Vieira et al., 2010; Bockheim et al., 2013). An exponential increase in studies related to permafrost state has also been observed in mountain environments, especially from highly populated regions (e.g., European Alps) with a major focus on geomorphological hazards (Kääb et al., 2005; Harris et al., 2009). In contrast, there is a significant lack of information on soil thermal dynamics in seasonal frost environments, with only a few studies focusing on midlatitude mountain ranges (e.g., Oliva et al., 2014b).

Soil thermal regime has major implications for terrestrial ecosystems in cold-climate environments since it comprises the physical, hydrological, geomorphological and biological processes affecting the soils. In this sense, in this special issue there is an outstanding example of the major interests in which soil scientists are working today. A wide range of topics have been analyzed with six main purposes:

- use of paleosols as indicators of environmental and climate change (Bockheim, 2013; Martínez Cortizas et al., 2014; Oliva et al., 2014a);

- characterization of physical and chemical properties of the soils (Navas et al., 2014; Palazón et al., 2014);

- response of the soil properties from fire events (Pereira et al., 2014; Tsibart et al., 2014);

- analysis of the biological and ecological processes in soils, with a focus on the carbon storage in permafrostaffected soils (Abakumov and Mukhametova, 2014; Zubrzycki et al., 2014);

- identification of the thermal properties of the active layer and permafrost (de Pablo et al., 2014; Michel et al., 2014); 
- understanding the interaction between the soils and geomorphology (Gómez-Ortiz et al., 2014; Poelking et al., 2014).

Most of the contributions to this special issue examine different topics within the cryospheric sciences, with the majority of papers centered on periglacial environments. Regarding the thermal state of the soil, 9 of the 13 contributions are focused on permafrost regions and only 4 in seasonal frost environments. Geographically, there has been a major contribution from researchers working in Antarctica (six papers), followed by the Arctic (three papers), followed by mid- and high-latitude mountain ranges (three papers) and boreal environments (one paper).

The study of Cryosols has significantly increased over the last decade, especially in Antarctica (Schaefer et al., 2008; Simas et al., 2008; Moura et al., 2012). A thorough understanding of present-day soil processes in cold environments can be used in a reverse manner to infer past environmental and climatic conditions based on the detailed analysis of sedimentological sequences. With this purpose, Bockheim (2013), Oliva et al. (2014a) and Martínez Cortizas et al. (2014) studied the paleoenvironmental evolution in different sites from polar regions at different timescales. Thanks to his extensive experience in mapping, classifying and describing Cryosols in many areas across Antarctica (e.g., Bockheim, 2002, 2010), Bockheim (2013) published the first paper fully focused on paleosols as indicators of past environmental conditions in the Antarctic continent. Some of the paleosols discussed in his paper show a surprisingly old age, which must be related to the extreme cold and dryness prevailing for 40 millennia in ice-free areas of the interior of the continent. Oliva et al. (2014a) studied two sedimentological sequences in central Svalbard from a geochronological and geochemical point of view. This paper provides insights into the environmental and climate evolution in the High Arctic over the last three millennia, showing evidence of significant changes in the climate conditions prevailing in the area during the mid-late Holocene. Using another natural archive, Martínez Cortizas et al. (2014) analyzed the sediments from a lake in Antarctica in order to reconstruct the environmental and climate history of the last $1.6 \mathrm{kyr}$ in the westernmost part of the South Shetland Islands. The accurate geochemical study of the sediment composition has revealed different climate phases as well as periods of volcanic eruptions on nearby Deception Island.

Over the last several decades there has also been a major advance in the understanding of the physical and chemical composition of Cryosols (Navas et al., 2005, 2008). The chemical signature of the soils may change with time (Navas et al., 2008). In this sense, Navas et al. (2014) show how the study of the fallout radionuclides and environmental radionuclides in soil profiles in recently deglaciated environments can reveal patterns of ice retreat. The study case for western Norway, an area with a large amount of information about historical glacier dynamics (Nussbaumer et al., 2011), can be therefore applied to other glaciated environments with little information about recent evolution from other proxies. In addition, the study of the chemical composition of the presentday soils combined with models can contribute to understand the source of the sediments being mobilized down-slope at an alpine catchment scale, such as that shown by Palazón et al. (2014). This interesting study can be also used to identify geomorphically stable areas and potentially instable slopes, with large socioeconomical implications.

Fire is a natural disturbance in boreal ecosystems with important implications on vegetation dynamics and soil composition (Vanha-Majamaa et al., 2007; Granstrom, 2011; Pereira et al., 2013a). Surface and low-mean-intensity fires are common in European boreal ecosystems (Gromtsev, 2002; Wooster and Zhang, 2004; Pereira et al., 2013b). Pereira et al. (2014) observed a darkening of the soil during the first 9 months after a low-severity grassland fire. Soil organic matter was also significantly higher in the burnt plot than in the unburnt one during the first 2 months after the fire. Fine earth soil water repellency (SWR) decreased with the time in the burnt plot. The differences between the burnt and unburnt plot were significantly different during the two first months after the fire. Tsibart et al. (2014) observed that Polyciclic aromatic hydrocarbons (PAHs) increased in burnt Histosols, especially in the new pyrogenic layers. The authors also observed that the concentration of PAHs was higher in the recent burnt areas in comparison to the older ones.

In connection with these scientific advances on the knowledge about the physical and chemical composition of the soils, there has been a recent increase in the number of papers focusing in the relationship between carbon and soils (Zubrzycki et al., 2014). Greenhouse gases such as carbon dioxide and methane trapped in frozen soils may be released to the atmosphere as a consequence of increasing temperatures in permafrost environments and amplify warming, especially in the Arctic (Tarnocai et al., 2009; Natali et al., 2014). Abakumov and Mukhametova (2014) presented the case of several sites around Russian bases in Antarctica, showing the very significant differences between the subAntarctic areas and those located on the continent, where temperatures are much colder. Those located in northern latitudes show higher total soil organic content, higher microbial carbon content, basal respiration and metabolic activity levels than those on the continent. However, studies of carbon storage in soils have been by far more abundant in the Arctic than in Antarctica, because of the geopolitical significance of the Northern Hemisphere (McGuire et al., 2009). Zubrzycki et al. (2014) summarized the current state of the knowledge on the carbon pool in permafrost-affected soils in Russian Arctic and propose some guidelines for future investigations on these topics.

The major control for the release of the greenhouse gases in permafrost regions comes from permafrost thawing. Therefore, the monitoring of the thermal state of the per- 
mafrost is of crucial importance to assess present and future trends that may have implications for global climate. Two papers in the special issue examine the dynamics of the active layer in maritime Antarctica, an area close to the climate boundaries of permafrost about which there is as yet little information (Vieira et al., 2010; Bockheim et al., 2013). De Pablo et al. (2014) characterize the thermal dynamics of the active layer on Byers Peninsula (Livingstone Island), the largest ice-free area of the South Shetland Islands. Michel et al. (2014) also analyze the rhythm of freezing and thawing in a permafrost environment on Fildes Peninsula (King George Island), the second largest ice-free area in the same archipelago.

The study of soil temperatures is also necessary in order to understand the major geomorphological processes occurring in terrestrial ecosystems. There is a close relationship between soil temperatures and the periglacial landscape. Poelking et al. (2014) provide a detailed analysis of the interaction between soils, vegetation and landforms in a deglaciated environment in maritime Antarctica. Gómez-Ortiz et al. (2014) analyzed the response of a marginal permafrost environment in the high semiarid Mediterranean massif of the Sierra Nevada to the recent climate warming recorded in southern Spain over the last decades.

The wide variety of contributions included in this special issue and their outstanding scientific level show evidence of the high quality of the research that is being conducted nowadays on soil studies in cold environments.

Acknowledgements. The first author wants to acknowledge the financial support received from the research project HOLOANTAR (Holocene environmental change in the maritime Antarctic. Interactions between permafrost and the lacustrine environment, PTDC/CTE-GIX/119582/2010), funded by the Portuguese Science Foundation and the sponsorship of the AXA Research Fund. The second author is thankful for the support of the projects LITFIRE (Fire effects on Lithuanian soils and ecosystems, MIP-048/2011), funded by the Lithuanian Research; POSTFIRE (Soil quality, erosion control and plant cover recovery under different post-fire management scenarios, CGL2013-47862-C2-1-R), funded by the Spanish Ministry of Economy and Competitiveness; RECARE (Preventing and Remediating Degradation of Soils in Europe Through Land Care, FP7-ENV-2013-TWO STAGE), funded by the European Commission; and for the COST action ES1306 (Connecting European connectivity research). The last author acknowledges the CICYT project EROMED (CGL2011-25486), funded by the Spanish Ministry of Science and Innovation.

\section{References}

Abakumov, E. and Mukhametova, N.: Microbial biomass and basal respiration of selected Sub-Antarctic and Antarctic soils in the areas of some Russian polar stations, Solid Earth, 5, 705-712, doi:10.5194/se-5-705-2014, 2014.
Bockheim, J. G.: Landform and soil development in the McMurdo Dry Valleys: a regional synthesis, Arct. Antarct. Alp. Res., 34, 308-317, 2002.

Bockheim, J. G.: Evolution of desert pavements and the vesicular layer in soils of the Transantarctic Mountains, Geomorphology, 118, 433-443, 2010.

Bockheim, J. G.: Paleosols in the Transantarctic Mountains: indicators of environmental change, Solid Earth, 4, 451-459, doi:10.5194/se-4-451-2013, 2013.

Bockheim, J. G., Vieira, G., Ramos, M., López-Martínez, J., Serrano, E., Guglielmin, M., Wilhelm, K., and Nieuwendam, A.: Climate Warming and Permafrost Dynamics in the Antarctic Peninsula Region, Global Planet. Change, 100, 215-223, 2013.

de Pablo, M. A., Ramos, M., and Molina, A.: Thermal characterization of the active layer at the Limnopolar Lake CALM-S site on Byers Peninsula (Livingston Island), Antarctica, Solid Earth, 5, 721-739, doi:10.5194/se-5-721-2014, 2014.

Gómez-Ortiz, A., Oliva, M., Salvador-Franch, F., Salvà-Catarineu, M., Palacios, D., de Sanjosé-Blasco, J. J., Tanarro-García, L. M., Galindo-Zaldívar, J., and Sanz de Galdeano, C.: Degradation of buried ice and permafrost in the Veleta cirque (Sierra Nevada, Spain) from 2006 to 2013 as a response to recent climate trends, Solid Earth, 5, 979-993, doi:10.5194/se-5-979-2014, 2014.

Granstrom, A.: Fire management for biodiversity in the European boreal Forest, Scand. J. Forest Res., 3, 62-69, 2011.

Gromtsev, A.: Natural disturbance dynamics in the boreal forests of European Russia: A review, Silva Fenn., 36, 41-55, 2002.

Harris, C., Arenson, L. U., Christiansen, H. H., Etzelmüller, B., Frauenfelder, R., Gruber, S., Haeberli, W., Hauck, C., Hölzle, M., Humlum, O., Isaksen, K., Kääb, A., Lehning, M., Lütschg, M. A., Matsuoka, N., Murton, J. B., Nötzli, J., Phillips, M., Ross, N., Seppälä, M., Springman, S. M., and Vonder Mühll, D.: Permafrost and climate in Europe: geomorphological impacts, hazard assessment and geotechnical response, Earth-Sci. Rev., 92, 117-171, 2009.

Kääb, A., Reynolds, J. M., and Haeberli, W.: Glacier and permafrost hazards in high mountains, in: Global Change and Mountain Regions, edited by: Huber, U. M., Bugmann, H. K. M., and Reasoner, M. A., Adv. Glob. Change Res., Springer, Dordrecht, 23, 225-234, 2005.

Martínez Cortizas, A., Rozas Muñiz, I., Taboada, T., Toro, M., Granados, I., Giralt, S., and Pla-Rabés, S.: Factors controlling the geochemical composition of Limnopolar Lake sediments (Byers Peninsula, Livingston Island, South Shetland Island, Antarctica) during the last ca. 1600 years, Solid Earth, 5, 651-663, doi:10.5194/se-5-651-2014, 2014.

McGuire, A. D., Anderson, L. G., Christensen, T. R., Dallimore, S., Guo, L., Hayes, D. J., Heimann, M., Lorenson, T. D., Macdonald, R. W., and Roulet, N.: Sensitivity of the carbon cycle in the Arctic to climate change, Ecol. Monogr., 79, 523-555, 2009.

Michel, R. F. M., Schaefer, C. E. G. R., Simas, F. N. B., Francelino, M. R., Fernandes-Filho, E. I., Lyra, G. B., and Bockheim, J. G.: Active layer thermal monitoring at Fildes Peninsula, King George Island, Maritime Antarctica, Solid Earth Discuss., 6, 1423-1449, doi:10.5194/sed-6-1423-2014, 2014.

Moura, P. A., Francelino, M. R., Schaefer, C., Simas, F., and de Mendonça, B.: Distribution and characterization of soils and landform relationships in Byers Peninsula, Livingston Island, Maritime Antarctica, Geomorphology, 155-156, 45-54, 2012. 
Natali, S. M., Schuur, E. A. G., Webb, E. E., Hicks Pries, C. E., and Crummer, K. G.: Permafrost degradation stimulates carbon loss from experimentally warmed tundra. Ecology, 95, 602-608, 2014.

Navas, A., Soto, J., and López-Martínez, J.: Radionuclides in soils of Byers Peninsula, South Shetland Islands, Western Antarctica, Appl. Radiat. Isotopes, 62, 809-816, 2005.

Navas, A., López-Martinez, J., Casas, J., Machín, J., Durán, J. J., Serrano, E., Cuchí, J. A., and Mink, S.: Soil characteristics on varying lithological substrates in the South Shetland Islands, maritime Antarctica, Geoderma, 144, 123-139, 2008.

Navas, A., Laute, K., Beylich, A. A., and Gaspar, L.: Variations of soil profile characteristics due to varying time spans since ice retreat in the inner Nordfjord, western Norway, Solid Earth, 5, 485-498, doi:10.5194/se-5-485-2014, 2014.

Nelson, F. E., Anisimov, O. A., and Shiklomanov, N. I.: Climate change and hazard zonation in the circum-Arctic permafrost regions, Nat. Hazards, 26, 203-225, 2002.

Nussbaumer, S. U., Nesje, A., and Zumbühl, H. J.: Historical glacier fluctuations of Jostedalsbreen and Folgefonna (southern Norway) reassessed by new pictorial and written evidence, The Holocene, 21, 455-471, 2011.

Oliva, M., Vieira, G., Pina, P., Pereira, P., Neves, M., and Freitas, M. C.: Sedimentological characteristics of ice-wedge polygon terrain in Adventdalen (Svalbard) - environmental and climatic implications for the late Holocene, Solid Earth, 5, 901914, doi:10.5194/se-5-901-2014, 2014a.

Oliva, M., Gómez Ortiz, A., Salvador, F., Salvà, M., Pererira, P., and Geraldes, M.: Long term soil temperature dynamics in the Sierra Nevada, Spain. Geoderma, 235-236, 170-181, 2014b.

Palazón, L., Gaspar, L., Latorre, B., Blake, W. H., and Navas, A.: Evaluating the importance of surface soil contributions to reservoir sediment in alpine environments: a combined modelling and fingerprinting approach in the Posets-Maladeta Natural Park, Solid Earth, 5, 963-978, doi:10.5194/se-5-963-2014, 2014.

Pereira, P., Cerdà, A., Jordán, A., Bolutiene, V., Úbeda, X., Pranskevicius, M., and Mataix-Solera, J.: Spatio-temporal vegetation recuperation after a grassland fire in Lithuania, Procedia Environmental Sciences, 19, 856-864, 2013a.

Pereira, P., Cerdà, A., Úbeda, X., Mataix-Solera, J., Martin, D., Jordán, A., and Burguet, M.: Spatial models for monitoring the spatio-temporal evolution of ashes after fire - a case study of a burnt grassland in Lithuania, Solid Earth, 4, 153-165, doi:10.5194/se-4-153-2013, 2013b.

Pereira, P., Úbeda, X., Mataix-Solera, J., Oliva, M., and Novara, A.: Short-term changes in soil Munsell colour value, organic matter content and soil water repellency after a spring grassland fire in Lithuania, Solid Earth, 5, 209-225, doi:10.5194/se-5-209-2014, 2014.
Poelking, E. L., Schaefer, C. E. R., Fernandes Filho, E. I., de Andrade, A. M., and Spielmann, A. A.: Soil-landform-plant communities relationships of a periglacial landscape at Potter Peninsula, Maritime Antarctica, Solid Earth Discuss., 6, 2261-2292, doi:10.5194/sed-6-2261-2014, 2014.

Romanovsky, V. E., Smith, S. L., and Christiansen, H. H.: Permafrost thermal state in the polar Northern Hemisphere during the International Polar Year 2007-2009: a synthesis. Permafrost Periglac., 21, 106-116, 2010.

Schaefer, C., Simas, F., Gilkes, R., Mathison, C., da Costa, L. M., and Albuquerque, M.: Micromorphology and microchemistry of selected Cryosols from maritime Antarctica, Geoderma, 144, 104-115, 2008.

Simas, F., Schaefer, C., Albuquerque, M., Francelino, M., Fernandes Filho, E. I., and Costa, L. M.: Genesis, properties and classification of Cryosols from Admiralty Bay, Maritime Antarctica, Geoderma, 144,, 116-122, 2008.

Tarnocai, C., Canadell, J. G., Schuur, E. A. G., Kuhry, P., Mazhitova, G., and Zimov, S.: Soil organic carbon pools in the northern circumpolar permafrost region. Global Biogeochem., Cy., 23, GB2023, doi:10.1029/2008GB003327, 2009.

Tsibart, A. S., Gennadiev, A. N., and Koshovskii, T. S.: Polycyclic aromatic hydrocarbons in post-pyrogenic soils of drained peatlands in West Meshchera (Moscow Region, Russia), Solid Earth Discuss., 6, 1265-1298, doi:10.5194/sed-6-1265-2014, 2014.

Vanha-Majamaa, I., Lilija, S., Ryoma, R., Kotiaho, J. S., LaakaLindberg, S., Lindberg, H., Puttonen, P., Tamminen, P., Toivanen, T., and Kuuluvainen, T.: Rehabilitating boreal forest structure and species composition in Finland thought logging, dead wood creation and fire: The EVO experiment, Forest Ecol. Manag., 250, 77-88, 2007

Vieira, G., Bockheim, J., Guglielmin, M., Balks, M., Abramov, A. A., Boelhouwers, J., Cannone, N., Ganzert, L., Gilichinsky, D. A., Goryachkin, S., López-Martínez, J., Meiklejohn, I., Raffi, R., Ramos, M., Schaefer, C., Serrano, E., Simas, F., Sletten, R., and Wagner, D.: Thermal state of permafrost and active-layer monitoring in the antarctic: Advances during the international polar year 2007-2009. Permafrost Periglac. Process., 21, 182 197, doi:10.1002/ppp.685, 2010.

Wooster, M. J. and Zhang, Y. H.: Boreal forests fires burn less intensively in Russia than in North America, Geophys. Res. Lett., 31, 1-3, 2004.

Zubrzycki, S., Kutzbach, L., and Pfeiffer, E.-M.: Permafrostaffected soils and their carbon pools with a focus on the Russian Arctic, Solid Earth, 5, 595-609, doi10.5194/se-5-595-2014, 2014. 